\title{
Aktivitas ekstrak heksan tumbuhan patah tulang Euphorbia tirucalli (Euphorbiaceace) terhadap telur Crocidolomia pavonana (Lepidoptera: Crambidae)
}

\author{
Activity of hexane extract of milkbush Euphorbia tirucalli (Euphorbiaceace) againsts the egg of \\ Crocidolomia pavonana (Lepidoptera: Crambidae)
}

\author{
ARNETI", UJANG KHAIRUL, NHYRA KAMALA PUTRI \\ Program Studi Agroteknologi, Fakultas Pertanian, Universitas Andalas, Kampus Unand Limau Manis, Kecamatan Pauh, Padang 25163, Sumatera Barat, \\ PO Box. 14. Tel.: +62-751-72776, 777641, Fax..+62-751-72776, "email: arneti_astri@yahoo.com
}

Manuskrip diterima: 31 Maret 2016. Revisi disetujui: 2 Agustus 2016.

\begin{abstract}
Abstrak. Arneti, Khairul U, Putri NK. 2016. Aktivitas ekstrak heksan tumbuhan patah tulang Euphorbia tirucalli (Euphorbiaceace) terhadap telur Crocidolomia pavonana (Lepidoptera: Crambidae). Pros Sem Nas Masy Biodiv Indon 2: 1-6. Penggunaan tumbuhan patah tulang (Euphorbia tirucalli L.) sebagai insektisida nabati merupakan salah satu teknik pengendalian Crocidolomia pavonana yang sesuai dengan konsep pengendalian hama terpadu (PHT). Penelitian ini bertujuan untuk mengetahui pengaruh aplikasi ekstrak heksan tumbuhan patah tulang terhadap penekanan terhadap penetasan telur C. pavonana pada umur yang berbeda. Penelitian dilakukan dengan menggunakan rancangan acak lengkap (RAL) dengan 4 perlakuan dan 7 ulangan. Perlakuan berupa aplikasi ekstrak heksan tumbuhan patah tulang pada telur C. pavonana umur 1, 2, 3, dan 4 hari setelah telur diletakkan. Ekstrak heksan tumbuhan patah tulang diaplikasikan dengan menggunakan metode celup pada konsentrasi $0,23 \%$. Hasil penelitian menunjukkan bahwa ekstrak heksan tumbuhan patah tulang pada konsentrasi 0,23\% mampu menekan penetasan telur C. pavonana umur 1 hingga 3 hari dengan persentase penetasan telur berturut-turut $12,72 \%, 36,50 \%$, dan $44,00 \%$, serta persentase aktivitas ovisidal berturut-turut $87,15 \%$, 63,32\%, dan $55,42 \%$. Ekstrak heksan tumbuhan patah tulang tidak mempengaruhi lama perkembangan telur C. pavonana.
\end{abstract}

Kata kunci: Aktivitas ovisidal, Crocidolomia pavonana, Euphorbia tirucalli, heksan, patah tulang

\begin{abstract}
Arneti, Khairul U, Putri NK. 2016. Activity of hexane extract of milkbush Euphorbia tirucalli (Euphorbiaceace) againsts the egg of Crocidolomia pavonana (Lepidoptera: Crambidae). Pros Sem Nas Masy Biodiv Indon 2: 1-6. The using of milkbush (Euphorbia tirucalli L.) as a botanical insecticide is one of pest management techniques for Crocidolomia pavonana which compatible with the integrated pest management (IPM) concept. The purpose of research was to determine the effect of hexane extract of milkbush in suppresing the eggs hatch of $C$. pavonana in different ages. The research was conducted by using a completely randomized design (CRD) which consisted of 4 treatments and 7 replications. The treatments were application of hexane extract of milkbush on different ages of C. pavonana eggs 1, 2, 3 and 4 days after laid. Hexane extract of milkbush was applied by using a dying methode at concentration $0.23 \%$. The result showed that hexane extract of milkbush at concentration $0.23 \%$ could suppress the eggs hatch of $C$. pavonana at age ranging from 1 until 3 days with the eggs hatch percentages were $12.72 \%, 36.50 \%$ and $44.00 \%$, respectively, and ovicidal activity percentages were $87.15 \%, 63.32 \%$ and $55.42 \%$, respectively. Hexane extract of milkbush did not influence $C$. pavonana eggs incubation period.
\end{abstract}

Kata kunci: Crocidolomia pavonana, Euphorbia tirucalli, hexane, milkbush, ovicidal activity

\section{PENDAHULUAN}

Ulat krop kubis (Crocidolomia pavonana) merupakan salah satu hama utama pada tanaman kubis (Kalshoven 1981). Serangan C. pavonana menyebabkan kehilangan hasil tanaman kubis hingga $100 \%$ pada musim kemarau (Sastrosiswojo dan Setiawati 1990). Oleh karena itu diperlukan upaya pengendalian hama C. pavonana untuk menekan kerugian yang ditimbulkannya.

Upaya pengendalian organisme pengganggu tanaman (OPT) ditetapkan dengan sistem pengendalian hama terpadu (PHT). Pada sistem PHT ditekankan penggunaan teknik pengendalian yang selaras dengan kelestarian lingkungan. Pengendalian hama secara kimiawi dengan insektisida hanya dilakukan apabila pengendalian secara nonkimiawi tidak lagi memberikan hasil yang optimal. Insektisida yang memenuhi syarat keamanan terhadap organisme bukan sasaran dan lingkungan yang sesuai dengan konsep PHT adalah insektisida nabati (Martono et al. 2004).

Insektisida nabati dapat dijadikan alternatif pengganti insektisida sintetik. Insektisida nabati selain efektif terhadap hama sasaran, juga memiliki keunggulan lain seperti mudah terurai di alam, relatif aman terhadap 
organisme bukan sasaran, dapat dipadukan dengan komponen pengendalian lain, dan dapat memperlambat laju resistensi hama (Leatemia 2003). Penggunaan tumbuhan sebagai sumber insektisida nabati dapat meningkatkan efisiensi pemanfaatan sumber daya lokal.

Tumbuhan dari golongan Euphorbiaceae dilaporkan berpotensi sebagai salah satu sumber insektisida nabati. Salah satu tumbuhan dari golongan Euphorbiaceae yang memiliki potensi untuk dikembangkan sebagai insektisida nabati adalah tumbuhan patah tulang (Euphorbia tirucalli L.). Dahan dan ranting patah tulang mengandung getah yang bersifat toksik bagi serangga hama. Kandungan kimia yang terdapat dalam getah tumbuhan tersebut berupa getah asam (latex acid) yang mengandung euphorbone, taraksasterol, lakterol, euphol, senyawa damar, kutschuk (zat karet), asam ellaf (Supriyanto dan Luviana 2010), alkaloid, tanin, flavonoid, steroid, triterpenoid, dan hidroquinon (Toana dan Nasir 2010).

Toana dan Nasir (2010) melaporkan bahwa tumbuhan patah tulang yang diekstrak dengan pelarut aseton dengan perlakuan konsentrasi $2 \%$ dapat menyebabkan mortalitas $50 \%$ pada larva Plutella xylostella. Hasil penelitian Mulya (2015) menunjukkan ekstrak heksan tumbuhan patah tulang pada konsentrasi $0,23 \%$ mampu menyebabkan mortalitas larva C. pavonana sebesar 50\%. Beberapa tumbuhan dari golongan Euphorbiaceae lainnya yang berpotensi sebagai insektisida nabati antara lain E. nivulla, E. pulcherrima, E. antiquorum (Uma et al. 2009), E. heterophylla (Kuppusamy dan Murugan 2008), dan Cleistanthus collinus (Arivolli dan Tennyson 2013).

Sasaran pengendalian pada stadia telur ditekankan pada upaya menekan penetasan telur C. pavonana sebelum larva masuk ke dalam krop. Dalam upaya menekan penetasan telur, umur telur saat perlakuan merupakan salah satu hal yang harus dipertimbangkan. Su dan Mulla (1998) menyatakan umur telur merupakan salah satu hal yang mempengaruhi efektivitas aktivitas ovisidal dalam menekan penetasan telur. Rajkumar dan Jebanesan (2008) melaporkan aktivitas ovisidal ekstrak Chenopodium ambrosioides (Chenopodiaceae) lebih tinggi pada telur Culex quinquefasciatus (Diptera: Culicidae) yang berumur lebih muda dibandingkan telur yang berumur lebih tua. Hasil penelitian Govindarajan (2009) menunjukkan efek ovisidal ekstrak Cassia fistula (Legumiosae) hanya terjadi pada telur Aedes aegypty (Diptera: Culicidae) pada saat telur yang diaplikasikan berumur 0 hari, serta tidak menunjukkan pengaruh pada telur umur 4, 8, 12, dan 24 hari saat aplikasi.

Pengendalian $C$. pavonana dilakukan berdasarkan pertimbangan sasaran pengendalian yang efektif. Salah satu sasaran pengendalian yang efektif adalah stadia telur. Telur merupakan fase perkembangan yang tidak aktif, sehingga cukup rentan terhadap pengaruh luar atau lingkungan (Wibowo et al. 2003). Oleh karena itu, penelitian ini bertujuan untuk mengetahui pengaruh aplikasi ekstrak heksan tumbuhan patah tulang terhadap penekanan penetasan telur C. pavonana pada berbagai umur telur.

\section{BAHAN DAN METODE}

Penelitian dilaksanakan di Laboratorium Bioekologi Serangga, Jurusan Hama dan Penyakit Tanaman, Fakultas Pertanian, Universitas Andalas, Padang dari bulan Februari sampai Mei 2015. Penelitian menggunakan rancangan acak lengkap (RAL) dengan 4 perlakuan dan 7 ulangan. Serangga uji yang digunakan adalah kelompok telur $C$. pavonana. Konsentrasi yang digunakan mengacu pada $\mathrm{LC}_{50}$ ekstrak heksan tumbuhan patah tulang terhadap larva C. pavonana yang diperoleh Mulya (2015). Perlakuan berupa aplikasi ekstrak heksan tumbuhan patah tulang dilakukan dengan konsentrasi $0,23 \%$ pada berbagai umur telur C. pavonana yaitu 1, 2, 3, dan 4 hari setelah telur diletakkan. Data yang diperoleh dianalisis dengan sidik ragam dan dilanjutkan dengan uji DNMRT pada taraf 5\%.

\section{Penyediaan bahan tanaman sumber ekstrak}

Tumbuhan patah tulang diperoleh dari Nagari Lubuk Pandan, Kecamatan 2x11 Enam Lingkung, Kabupaten Padang Pariaman. Batang dan daun tanaman patah tulang dipotong-potong dengan ukuran 0,5 cm. Potonganpotongan tersebut selanjutnya dikeringanginkan selama dua minggu. Setelah dikering angin, potongan-potongan tersebut dihancurkan dengan menggunakan blender hingga menjadi serbuk. Selanjutnya, serbuk tumbuhan patah tulang diayak dengan menggunakan ayakan dengan ukuran 0,5 mesh.

\section{Penyediaan pakan larva C. pavonana}

Larva C. pavonana diberi pakan daun brokoli yang berasal dari hasil penanaman benih brokoli Brassica oleraceae L. var. Sakata. Benih brokoli disemai pada nampan semai berukuran $100 \mathrm{~cm}$ x $50 \mathrm{~cm} \times 5 \mathrm{~cm}$ dan berisi 50 lubang tanam yang telah diisi media campuran tanah dan kompos dengan perbandingan 3:1. Pemupukan dengan pupuk majemuk NPK dilakukan beriringan dengan kegiatan penyemaian dengan dosis satu butir per lubang tanam. Bibit brokoli yang berumur 3 minggu setelah semai dipindahkan ke polibag ( $5 \mathrm{~kg}$ ) yang berisi campuran tanah dan pupuk kandang (3:1). Pemeliharaan dilakukan setiap hari yang meliputi penyiraman, penyiangan gulma, dan pengendalian hama secara mekanis jika ditemukan hama pada tanaman. Daun brokoli dari tanaman yang berumur $\geq 2$ bulan digunakan sebagai pakan larva C. pavonana.

\section{Pengadaan serangga uji}

Serangga uji yang digunakan adalah kelompok telur $C$. pavonana. Serangga uji diperoleh dari hasil perkembangan C. pavonana yang dimulai dari fase larva. Larva $C$. pavonana diperoleh dari hasil perbanyakan C. pavonana di Laboratorium Bioekologi Serangga. Larva tersebut dipelihara di dalam kotak pemeliharaan berukuran $30 \mathrm{~cm} \mathrm{x}$ $20 \mathrm{~cm}$ x $10 \mathrm{~cm}$. Bagian atas kotak pemeliharaan berjendela kain kasa. Larva diberi pakan daun brokoli yang masih segar dan bebas pestisida yang diganti setiap hari. Pada fase prapupa, larva $C$. pavonana dipindahkan ke kotak pemeliharaan lain dengan ukuran yang sama yang berisi serbuk gergaji sebagai media larva membentuk pupa. Setelah dua minggu, pupa dipindahkan ke dalam sangkar 
kain kasa berukuran $50 \mathrm{~cm}$ x $30 \mathrm{~cm}$ x $40 \mathrm{~cm}$. Imago yang muncul diberi pakan berupa madu yang diserapkan pada kapas dengan konsentrasi $10 \%$. Di dalam kurungan diletakkan satu atau dua helai daun brokoli yang ditempatkan dalam botol film berisi air sebagai tempat peletakan telur. Telur yang menempel pada daun dipindahkan ke cawan petri. Larva yang muncul dari telur yang menetas dipindahkan ke kotak pemeliharaan.

\section{Ekstraksi tumbuhan patah tulang}

Serbuk tumbuhan patah tulang dimasukkan ke dalam labu erlenmeyer $1000 \mathrm{ml}$ sebanyak $50 \mathrm{~g}$. Serbuk tersebut selanjutnya dilarutkan dalam n-heksan sebanyak $500 \mathrm{ml}$ dan dimaserasi selama 2 x 24 jam. Hasil perendaman disaring dengan corong kaca $(\mathrm{d}=9 \mathrm{~cm})$ beralaskan kertas saring. Filtrat hasil penyaringan ditampung dengan labu erlenmeyer yang telah diketahui bobotnya. Untuk menentukan bobot ekstrak, labu berisi ekstrak dikurangi dengan labu tanpa ekstrak. Selanjutnya, hasil penyaringan dipekatkan dengan menggunakan rotary evaporator pada suhu $50^{\circ} \mathrm{C}$ dan tekanan 500-600 mmHg. Ampas dibilas dengan pelarut yang sama dan disaring kembali. Penyaringan dilakukan sebanyak 3 kali. Cairan ekstrak yang diperoleh dari hasil evaporasi ditimbang dan disimpan dalam lemari pendingin pada suhu $4^{\circ} \mathrm{C}$ hingga digunakan untuk pengujian (Prijono 2003).

\section{Uji ekstrak heksan tumbuhan patah tulang sebagai insektisida}

Metode yang digunakan dalam pengujian ekstrak heksan tumbuhan patah tulang terhadap telur C. pavonana mengacu pada metode Suyanto dan Manan (2011) dan Artanti et al. (2013) yang telah dimodifikasi. Pengujian tersebut dilakukan dengan menggunakan metode celup.

Kelompok telur C. pavonana umur 1, 2, 3, dan 4 hari yang menempel pada daun brokoli dicelupkan ke dalam larutan ekstrak heksan tumbuhan patah tulang konsentrasi $0,23 \%$. Selanjutnya, kelompok telur dikeringanginkan dan dimasukkan ke dalam cawan petri (diameter $9 \mathrm{~cm}$ ) yang telah diberi alas tisu yang dibasahi air steril sehingga dalam kondisi lembap. Adapun pada perlakuan kontrol, kelompok telur dicelupkan ke dalam larutan yang terdiri dari larutan induk aseton metanol agristik $(3: 1: 0,2)$ yang diencerkan dengan akuades. Pengamatan dilakukan setiap hari setelah aplikasi dan dihitung jumlah telur yang menetas.

\section{Parameter pengamatan}

Persentase penetasan telur

Pengamatan terhadap persentase penetasan telur $C$. pavonana dilakukan setiap hari setelah aplikasi. Pengamatan dilakukan dengan menghitung jumlah telur yang menetas. Persentase penetasan telur dihitung dengan menggunakan rumus:

$$
\mathrm{A}=\frac{a}{2} \times 100 \%
$$

Keterangan:

$$
\begin{aligned}
& \mathrm{A}=\text { persentase penetasan telur }(\%) \\
& \mathrm{a}=\text { jumlah telur yang menetas } \\
& \mathrm{N}=\text { jumlah telur yang diletakkan }
\end{aligned}
$$

\section{Persentase aktivitas ovisidal}

Pengamatan aktivitas ovisidal ekstrak heksan tumbuhan patah tulang terhadap C. pavonana dilakukan dengan menghitung persentase telur yang menetas pada kontrol dan perlakuan. Persentase aktivitas ovisidal dihitung dengan menggunakan rumus (Tennyson et al. 2011) sebagai berikut:

$$
\mathrm{AO}=[(\mathrm{Tk}-\mathrm{Tp}) / \mathrm{Tk}] \times 100 \%
$$

Keterangan:

$\mathrm{AO}=$ persentase aktivitas ovisidal $(\%)$

$\mathrm{Tk}=$ persentase penetasan telur kontrol

$\mathrm{Tp}=$ persentase penetasan telur perlakuan

Lama stadia telur

Pengamatan dilakukan setiap hari sejak kelompok telur diletakkan pada daun tanaman brokoli hingga telur menetas.

\section{HASIL DAN PEMBAHASAN}

Ekstrak heksan tumbuhan patah tulang memiliki kemampuan yang berbeda dalam menekan penetasan telur C. pavonana pada berbagai umur telur yang berbeda. Ekstrak heksan tumbuhan patah tulang menunjukkan pengaruh nyata pada perlakuan telur umur 1 hingga 3 hari dengan persentase penetasan telur berturut-turut $12,72 \%$, $36,50 \%$, dan $44,00 \%$ (Tabel 1) serta aktivitas ovisidal berturut-turut $87,15 \%, 63,32 \%$, dan 55,42\% (Tabel 2).

\begin{tabular}{|c|c|c|}
\hline $\begin{array}{c}\text { Perlakuan pada } \\
\text { umur telur } \\
\text { (hari) }\end{array}$ & $\begin{array}{c}\text { Kontrol } \\
\text { (\%) }\end{array}$ & $\begin{array}{c}\text { Persentase } \\
\text { penetasan telur } C \text {. } \\
\text { pavonana }(\%)\end{array}$ \\
\hline 1 & $98,81 \pm 2,04^{\mathrm{a}}$ & $12,72 \pm 16,65^{\mathrm{c}}$ \\
\hline 2 & $99,38 \pm 1,64^{\mathrm{a}}$ & $36,50 \pm 9,04^{b}$ \\
\hline 3 & $98,03 \pm 1,65^{\mathrm{a}}$ & $44,00 \pm 10,16^{b}$ \\
\hline 4 & $99,52 \pm 1,26^{\mathrm{a}}$ & $96,00 \pm 10,58^{\mathrm{a}}$ \\
\hline $\mathrm{KK}=11,76 \%$ & & \\
\hline
\end{tabular}
Telur perlakuan umur 4 hari memiliki persentase penetasan telur $96,00 \%$ dan aktivitas ovisidal 3,65\%.

Tabel 1. Rata-rata persentase penetasan telur C. pavonana setelah aplikasi ekstrak heksan E. tirucalli.

Keterangan: Setiap angka rerata yang menunjukkan notasi huruf

\begin{tabular}{|c|c|}
\hline $\begin{array}{c}\begin{array}{c}\text { Perlakuan pada } \\
\text { umur telur } \\
\text { (hari) }\end{array} \\
\end{array}$ & $\begin{array}{c}\text { Persentase aktivitas ovisidal } \\
\text { E. tirucalli }(\%)\end{array}$ \\
\hline 1 & $87,15 \pm 13,18^{a}$ \\
\hline 2 & $63,32 \pm 8,84^{b}$ \\
\hline 3 & $55,42 \pm 10,34^{b}$ \\
\hline 4 & $3,65 \pm 6,99^{c}$ \\
\hline
\end{tabular}
yang sama artinya berbeda secara tidak nyata pada uji DNMRT taraf 5\%.

Tabel 2. Rata-rata persentase aktivitas ovisidal ekstrak heksan $E$. tirucalli terhadap berbagai umur telur C. pavonana.

Keterangan: Setiap angka rerata yang menunjukkan notasi huruf yang sama artinya berbeda secara tidak nyata pada uji DNMRT taraf $5 \%$. 
Perbedaan penekanan terhadap penetasan telur $C$. pavonana pada umur yang berbeda dengan pemberian ekstrak heksan tumbuhan patah tulang dapat dikaitkan dengan kontak ekstrak dengan kulit telur dan pengaruhnya terhadap perkembangan telur. Suyanto dan Manan (2011) melaporkan residu ekstrak biji nimba diduga mampu bertahan pada kulit telur dan membunuh embrio $C$. pavonana dengan penekanan penetasan telur sebesar $95 \%$. Hasil penelitian ini juga menunjukkan hal yang sama. Ekstrak heksan tumbuhan patah tulang diduga mampu bertahan pada kulit telur dan mengganggu fungsi korion dalam memfasilitasi proses respirasi. Gangguan dalam proses respirasi tersebut diduga menyebabkan gas-gas yang diperlukan dalam perkembangan embrio tidak tercukupi, sehingga perkembangan embrio terganggu atau embrio mengalami kematian dan tidak dapat menetas. Prijono (2006) menambahkan gangguan yang terjadi pada proses metabolisme serangga mempengaruhi perkembangan serangga.

Proses pertukaran gas pada telur C. pavonana terjadi melalui saluran mikrofil yang terdapat pada korion telur. Selama proses respirasi diperlukan gas oksigen dan nitrogen untuk mendukung perkembangan telur. Oksigen dibutuhkan untuk oksidasi lemak yang merupakan substrat metabolik utama, sedangkan nitrogen dibutuhkan dalam proses sintesis protein dan pembentukan sel. Kedua gas tersebut dibutuhkan dalam perkembangan inti sel hingga menjadi embrio yang sempurna (Chapman 1971; Tuft 1950). Penutupan saluran mikrofil oleh ekstrak heksan tumbuhan patah tulang memungkinkan terjadinya gangguan pada proses respirasi, sehingga proses perkembangan telur C. pavonana terganggu. Gangguan dalam proses respirasi tersebut diduga menyebabkan gasgas yang diperlukan dalam perkembangan embrio tidak tercukupi, sehingga perkembangan embrio terganggu atau embrio mengalami kematian dan telur tidak dapat menetas. Gangguan proses respirasi pada telur C. pavonana dengan berbagai umur yang berbeda juga memberikan pengaruh yang berbeda nyata terhadap penekanan penetasan telur.

Penekanan penetasan telur tertinggi terjadi pada telur perlakuan umur 1 hari dengan persentase penetasan telur $12,72 \%$ dan persentase aktivitas ovisidal $87,15 \%$. Pada telur perlakuan umur 1 hari diduga kulit telurnya masih bersifat lentur, sehingga ekstrak heksan tumbuhan patah tulang dapat terserap ke dalam korion. Skudlik et al. (2005) melaporkan bahwa telur Spodoptera exiqua (Lepidoptera: Noctuidae) yang baru diletakkan bersifat lentur dan berkilau dan mulai mengeras beberapa jam kemudian. Tahap akhir koriogenesis yaitu pengerasan korion yang terjadi setelah oviposisi (Margaritis 1985). Sastrosiswojo dan Setiawati (1990) menyatakan bahwa imago betina $C$. pavonana melakukan oviposisi pada malam hari. Da Silva et al. (2013) menambahkan pada tahap awal perkembangan telur, tingkat maturasi (kematangan) telur masih rendah. Korion yang masih lentur pada telur yang masih muda memungkinkan ekstrak heksan tumbuhan patah tulang terserap ke dalam korion dan berpeluang lebih besar untuk menghalangi terjadinya proses respirasi dibandingkan telur umur 2 hingga 4 hari.
Penyerapan ekstrak heksan tumbuhan patah tulang pada telur umur 1 hari diduga tidak mencapai lapisan dalam telur. Pada saat oviposisi, telur serangga telah memiliki korion dan lapisan lilin yang terdapat di bawah korion. Meskipun korion belum mengeras, ekstrak tanaman patah tulang tidak dapat masuk ke dalam lapisan dalam telur dan merusak embrio karena lapisan lilin telah terbentuk (Chapman 1971; Margaritis 1985).

Penekanan penetasan telur perlakuan umur 2 dan 3 hari oleh ekstrak heksan tumbuhan patah tulang lebih rendah dibanding telur perlakuan umur 1 hari. Pada telur umur 2 dan 3 hari diduga korion telah mengeras, sehingga ekstrak heksan tumbuhan patah tulang tidak dapat terserap ke dalam lapisan korion. Ekstrak heksan tumbuhan patah tulang diduga hanya kontak dengan lapisan luar korion dan menutup saluran mikrofil. Penutupan saluran mikrofil pada telur umur 2 dan 3 hari yang masih mengalami perkembangan menyebabkan terganggunya proses perkembangan telur karena suplai oksigen dan nitrogen tidak tercukupi.

Kegagalan penetasan telur akibat perlakuan ekstrak heksan tumbuhan patah tulang ditunjukkan pada telur umur 1 hingga 3 hari, sedangkan telur umur 4 hari diduga tidak mengalami kegagalan penetasan. Telur perlakuan umur 4 hari memiliki persentase penetasan tertinggi yaitu 96,00\% dan persentase aktivitas ovisidal terendah yaitu 3,65\%. Hal ini diduga karena proses perkembangan embrio masih berlangsung pada telur umur 1 hingga 3 hari, sedangkan telur umur 4 hari diduga telah memasuki tahap akhir embriogenesis. Pada umur 4 hari diduga telur telah matang dan siap untuk menetas. Sari dan Prijono (2004) melaporkan pada saat telur akan menetas, tampak bayangan warna cokelat tua dari bagian kepala calon larva. Meskipun terjadi kontak dengan ekstrak heksan tumbuhan patah tulang dengan telur umur 4 hari, namun perlakuan ekstrak heksan tumbuhan patah tulang tidak mempengaruhi penetasan telur karena telur telah matang dan siap untuk menetas.

Semakin muda umur telur C. pavonana yang diaplikasikan ekstrak heksan tumbuhan patah tulang, semakin besar peluang kegagalan telur untuk menetas, hal ini diduga karena telur pada umur muda masih dalam tahap awal perkembangan. Penurunan penekanan penetasan telur dengan pertambahan umur telur dipengaruhi oleh umur embrio pada telur saat perlakuan. Kuppusamy dan Murugan (2008) melaporkan bahwa ekstrak etanol Euphorbia heterophylla (Euphorbiaceae) lebih efektif dalam menghambat penetasan telur Culex quinquefasciatus (Diptera: Culicidae) yang baru diletakkan daripada telur yang berumur lebih tua. Rajkumar dan Jebanesan (2008) juga melaporkan bahwa telur Culex quinquefasciatus (Diptera: Culicidae) lebih rentan terhadap aktivitas ovisidal Chenopodium ambrosioides (Chenopodiaceae) pada umur yang lebih muda daripada telur yang berumur lebih tua. Su dan Mulla (2008) melaporkan aktivitas ovisidal azadirachtin (AZ) terhadap telur Culex tarsalis (Diptera: Culicidae) terjadi pada tahap awal perkembangan telur, yaitu sebelum telur berumur 4 hari. Hasil penelitian Govindarajan (2009) menunjukkan efek ovisidal ekstrak Cassia fistula (Legumiosae) hanya terjadi pada telur Aedes aegypty (Diptera: Culicidae) pada saat telur yang 
diaplikasikan berumur 0 hari, dan tidak menunjukkan pengaruh mematikan pada telur saat aplikasi umur 4, 8, 12, dan 24 hari. Da Silva et al. (2013) juga melaporkan aktivitas ovisidal Natuneem, formulasi komersial dari minyak nimba Azadirachta indica, terjadi pada telur Diatraea saccharalis (Lepidoptera: Crambidae) saat tahap awal perkembangan telur yaitu pada umur 1, 2, dan 3 hari. Dalam penelitian tersebut dijelaskan bahwa telur $D$. saccharalis yang berumur lebih tua lebih tahan terhadap ekstrak tumbuhan nimba karena tingkat maturasi (kematangan) yang lebih tinggi, serta menyulitkan ekstrak tumbuhan untuk masuk ke dalam telur.

Kemampuan ekstrak heksan tumbuhan patah tulang untuk mengadakan kontak dengan telur C. pavonana dan menekan penetasan telur C. pavonana umur 1 hingga 3 hari dipengaruhi oleh senyawa aktif yang terdapat dalam ekstrak tumbuhan patah tulang. Mwine et al. (2010) menyatakan bahwa tumbuhan patah tulang mengandung senyawa lateks yang bersifat toksik terhadap serangga dan bersifat aktif pada waktu yang singkat. Enam senyawa metabolit yang terkandung dalam tanaman patah tulang yang diekstrak dengan pelarut aseton, yaitu alkaloid, tanin, flavonoid, steroid, triterpenoid, dan hidroquinon, dapat menyebabkan mortalitas $50 \%$ pada larva Plutella xylostella (Toana dan Nasir 2010). Senyawa lateks tersebut dapat mempengaruhi telur pada tahap awal perkembangan telur namun tidak mempengaruhi tahap akhir perkembangan telur.

Hasil pengamatan menunjukkan bahwa telur yang diperlakukan dengan ekstrak heksan tumbuhan patah tulang yang tidak menetas mengalami perubahan warna menjadi hijau tua dan cokelat kehitaman (Gambar 1).

Suyanto dan Manan (2011) melaporkan telur C. pavonana (Lepidoptera: Crambidae) yang diperlakukan dengan ekstrak Azadirachta indica (Meliaceae) yang tidak menetas mengalami perubahan warna menjadi kekuningan, kemudian berubah warna menjadi kecokelatan dan ditumbuhi jamur saprofitik. Hasil penelitian Da Silva et al. (2013) juga menunjukkan terjadinya perubahan warna pada telur Diatraea saccharalis (Lepidoptera: Crambidae) menjadi lebih gelap dan beberapa larva yang terbentuk gagal untuk keluar dari telur setelah perlakuan formulasi komersial dari minyak nimba (Natuneem). Adapun telur

kontrol mengalami perubahan warna dari hijau, kemudian pada hari selanjutnya menjadi kuning, cokelat kemerahan, dan hitam kelabu sebelum menetas.

Beberapa tumbuhan Euphorbiaceae dilaporkan memiliki aktivitas ovisidal bagi serangga. Kuppusamy dan Murugan (2008) melaporkan ekstrak etanol E. heterophylla (Euphorbiaceae) bersifat ovisidal bagi telur Culex quinquefasciatus. Tennyson et al. (2011) melaporkan bahwa Cleistanthus collinus (Euphorbiaceae) yang diekstrak dengan etil asetat efektif menghambat penetasan telur dan memiliki aktivitas ovisidal terhadap telur Culex quinquefasciatus mencapai $64,60 \%$. Arivoli dan Tennyson (2013) juga melaporkan C. collinus yang diekstrak dengan heksan memiliki aktivitas ovisidal di atas $75 \%$ pada Spodoptera litura.

Ekstrak heksan tumbuhan patah tulang mampu menekan penetasan telur C. pavonana pada umur perlakuan 1 hingga 3 hari, tetapi tidak mempengaruhi lama perkembangan telur (Tabel 1).

Telur perlakuan umur 1 hingga 4 hari yang dicelupkan ke dalam ekstrak heksan tumbuhan patah tulang yang berhasil menetas mengalami masa perkembangan telur selama 4 hari pada suhu kisaran $27-29^{\circ} \mathrm{C}$. Masa perkembangan ini sama dengan lama masa perkembangan telur kontrol. Sastrosiswojo dan Setiawati (1990) melaporkan lama periode inkubasi telur C. pavonana sekitar 4 hari (3-6 hari) pada suhu optimal $26,0-33,2^{\circ} \mathrm{C}$.

Dari penelitian ini, diperoleh kesimpulan bahwa ekstrak heksan tumbuhan patah tulang mampu menekan penetasan telur C. pavonana umur 1 hingga 3 hari, tetapi tidak berpengaruh terhadap lama perkembangan telur $C$. pavonana. Semakin muda umur telur C. pavonana, semakin besar penekanan penetasan telur.

Tabel 1. Lama stadia telur C. pavonana setelah dicelup ke dalam ekstrak heksan tumbuhan patah tulang.

\begin{tabular}{lccc}
\hline \multirow{2}{*}{$\begin{array}{c}\text { Umur telur } \\
\text { (hari) }\end{array}$} & \multicolumn{2}{c}{ Lama stadia telur (hari) } \\
\cline { 2 - 4 } & & Kontrol & Perlakuan \\
\hline 1 & 4,0 & 4,0 \\
2 & 4,0 & 4,0 \\
3 & 4,0 & 4,0 \\
4 & 4,0 & 4,0 \\
\hline
\end{tabular}

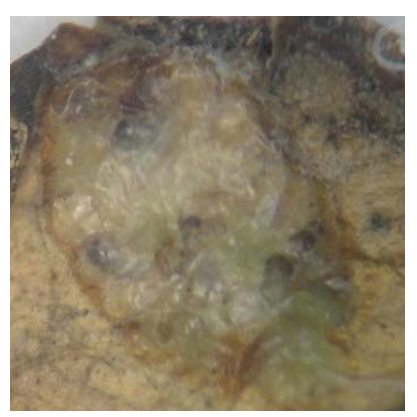

C

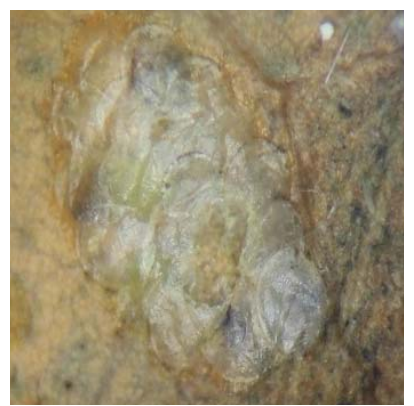

D

Gambar 1. Perubahan warna telur C. pavonana setelah telur menetas hasil perlakuan ekstrak heksan tumbuhan patah tulang terhadap berbagai umur telur. (A) Telur perlakuan umur 1 hari, (B) telur pelakuan umur 2 hari, C) telur perlakuan umur 3 hari, dan (D) telur perlakuan umur 4 hari. 


\section{UCAPAN TERIMA KASIH}

Terima kasih disampaikan kepada tim peneliti dan teknisi Laboratorium Bioekologi Serangga, Jurusan Hama dan Penyakit Tumbuhan, Fakultas Pertanian, Universitas Andalas, Padang yang telah membantu kelancaran penelitian ini.

\section{DAFTAR PUSTAKA}

Arivoli S, Tennyson S. 2013. Ovicidal activity of plant extracts agains Spodoptera litura (Fab) (Lepidotera: Noctiduae). Bull Env Pharmacol Life Sci 2(10): 140-145.

Artanti, Isnawati D, Trimulyono G et al. 2013. Cendawan entomopatogen Beauveria bassiana dalam mengendalikan telur hama penggerek ubi jalar (Cylas formicarius). Lentera Bio 2(1): 43-48.

Chapman RF. 1971. The insects: Structure and function. Second Edition. Elsevier North Holland, Inc., New York.

Da Silva CV, Schneider LCL, Conte H. 2013. Toxicity and residua activity of a commercial formulation of oil from Neem, Azadirachta indica A. Juss. (Meliaceae), in the embryonic development of Diatraea saccharalis F. (Lepidoptera: Crambidae). J Biofertil Biopestici 4(1): 1-5.

Govindarajan M. 2009. Bioefficasy of Cassia fistula Linn. (Leguminosae) leaf extract against chikungunya vector, Aedes aegypti (Diptera: Culicidae). Europ Rev for Med and Pharmacol Sci 13: 99-103.

Kalshoven LGE. 1981. The pests of crop in Indonesian. Revised and translated by PA van der Laan. PT. Ichtiar Baru-Van Hoveve, Jakarta.

Kuppusamy C, Murugan K. 2008. Mosquitocidal effect of Euphorbia heterophylla Lin. against the Bancroftian filariasis vector Culex quinquefasciatus Say (Diptera: Culicidae). International $\mathrm{J}$ of Integrative Biol 4(1): 34-39.

Leatemia JA. 2003. Development of a botanical insecticide from Ambon and surrounding areas (Indonesia) for local use. The University of British Columbia, Canada.

Margaritis LH. 1985. Structure and physiology of the egg shell. Insect Biochem and Molecular Biol 41: 101-108.

Martono B, Hadipoentyanti E, Udarno L. 2004. Plasma nutfah insektisida nabati. Perkembangan Teknologi Tanaman Rempah dan Obat 16(1): 43-59.

Mulya A. 2015. Aktivitas Ekstrak Tanaman Patah Tulang Euphorbia tirucalli L. (Euphorbiaceae) Terhadap Larva Crocidolomia pavonan
Fabricius (Lepidoptera: Crambidae). [Skripsi]. Universitas Andalas, Padang.

Mwine J, Damme PV, Jumba F. 2010. Evaluation of larvicidal properties of the latex of Euphorbia tirucalli L. (Euphorbiaceae) against larvae of Anopheles mosquitoes. J Med Plants Research 4(19): 1954-1959.

Prijono D. 2003. Teknik ekstraksi, uji hayati, dan aplikasi senyawa bioaktif tumbuhan. Institut Pertanian Bogor, Bogor.

Prijono D. 2006. Pedoman pengembangan dan pemanfaatan insektisida botani. Institut Pertanian Bogor, Bogor.

Rajkumar S, Jebanesan A. 2008. Bioactivity of Chenopodium ambrosioides L. (Family: Chenopodiaceae) against the filariasis vector Culex quinquefasciatus Say (Diptera: Culicidae). Can J of Pure and Appl Sci 2(1): 129-132.

Sari NJ, Prijono D. 2004. Perkembangan dan reproduksi Crocidolomia pavonana (F.) (Lepidoptera: Pyralidae) pada pakan alami dan semibuatan. J HPT Trop 4(2): 53-61.

Sastrosiswojo S, Setiawati W. 1990. Biology and control of Crocidolomia binotalis in Indonesia. Balai Penelitian Hortikultura Lembang, Bandung.

Skudlik J, Poprawa I, Rost MM. 2005. The egg capsule of Spodoptera exiqua Hubner, 1808 (Insecta, Lepidoptera, Noctuidae) morphology and ultrastructure. Zool Poloniae 50(1-4): 25-31.

$\mathrm{Su}$ T, Mulla MS. 1998. Ovicidal activity of neem products (azadirachtin) against Culex tarsalis and Culex Quinquefasciatus (Diptera: Culicidae). J of the American Mosquito Control Association 14(2): 204-209.

Supriyanto, Luviana I, Astria L. 2010. Pengaruh pemberian getah tanaman patah tulang secara topikal terhadap gambaran histopatologis dan ketebalan lapisan keratin kulit. Prosiding Seminar Biologi. Universitas Sebelas Maret, Surakarta.

Suyanto A, Manan A. 2011. Ekstrak biji nimba Azadirachta indica A. Juss pengaruhnya terhadap peletakan dan penetasan telur ulat hati kubis Crocidolomia pavonana F. J Pembangunan Pedesaan 11(1): 1-6.

Tennyson S, Ravindran KJ, Arivoli S. 2011. Screening of plant extracts for ovicidal against Culex quinquefasciatus Say (Diptera: Culicidae). Elixir Appl Botany 40: 5456-5460.

Toana MH, Nasir B. 2010. Studi bioaktif dan isolasi senyawa bioaktif tumbuhan Euphorbia tirucalli L. (Euphorbiaceae) sebagai insektisida botani alternatif. J Agroland 17(1): 47-55.

Tuft PH. 1950. The structure of the insect egg-shell in relation to the respiration of the embryo. J exp Biol 26: 327-334.

Uma MS, Prasanna PM, Manjunathareddy GV et al. 2009. Efficacy of some Euphorbiaceae plant extracts against cabbage diamondback moth, Plutella xylostella L. Karnataka J Agric Sci 22(3): 688-699.

Wibowo IH, Astirin OP, Budiharjo A. 2003. Pengaruh suhu dan fotoperiodisme terhadap lama stadia telur ulat sutera emas (Cricularia trifenestrata Helf.). Biosmart 6(1): 71-74. 